\title{
Comparison of State and Private Elementary School Students' Motivational Attitudes Towards the English Course-Adana Province Example in Turkey
}

\author{
Serap İDIKUT ${ }^{1}$, Mahmut Oğuz KUTLU ${ }^{1} \&$ Pınar AKMAN $^{1}$ \\ ${ }^{1}$ Department of Education Sciences, Çukurova University, Adana, Turkey \\ Correspondence: Pınar AKMAN, PhD Student, Department of Education Sciences, Çukurova University, Adana, \\ Turkey. E-mail: pinar_akman01@hotmail.com
}

Received: January 12, 2021 Accepted: February 14, 2021 Online Published: February 20, 2021

doi:10.5539/jel.v10n2p71 URL: https://doi.org/10.5539/jel.v10n2p71

\begin{abstract}
The role of motivation in foreign language teaching has been a debated issue for long years. One of the problematic issues is the motivation problem encountered in foreign language courses. Because, the most important factor affecting academic success is motivation. Most researchers argued that as the motivation level increases, the level of foreign language learning will increase and students will learn foreign languages more easily. In this research, motivation attitudes of state and private elementary school students in foreign language courses in Turkey were examined. At the same time, the relationship between foreign language and motivation attitude of state and private elementary school students was tried to be determined. The sample of the research is 747 students in 5th, 6th, 7th and 8th grades selected by random sampling from a Private Elementary School and a State Elementary School in Adana Province, Turkey, in 2018-2019 academic year. In the research, the participants were applied the Academic Motivation Scale-AMS and there was a significant effect on the motivation of different school type (state and private), gender, school and primary school was not examined. The difference between motivation levels of the students in state and private schools was tried to be determined. In the study, Pearson Product Moment Correlation Coefficiency and Independent Sample t-test Analysis were performed by using Statistical Package for Social Sciences-SPSS 22 Programme. According to the results, it was found that the motivation level differed according to the gender and school type.
\end{abstract}

Keywords: motivation, private elementary school, state elementary school, English teaching

\section{Introduction}

Motivation, in short, is the willingness of a person to make an effort to achieve a goal, and it is the power that encourages the individual to act and initiates the process of the activity. According to Başaran (2000), motivation is an external influence to meet or create a need. From a learning perspective, motivation is the desire and effort of an individual to learn. On the basis of motivation, there is a need waiting to reach satisfaction (Aktaş, 2011). In other words, motivation is called various factors that direct the behavior that energizes the targeted behavior (Atkinson, Atkinson, \& Hilgard, 1995).

Motivation has various sources. These are the psychological, physiological and social needs of the person and, according to Koçel (1995), the most striking feature of motivation is its individuality. What motivates one person may not motivate the other person. At the same time, the motivation techniques used in the learning environment may vary from individual to individual.

Steers and Porter (1991) stated that motivation is the main factor that gives power to an individual's behavior, manages and determines its continuity. Ignoring student motivation can be a failure in the learning process (Acat \& Köşgeroğlu, 2006). According to Aydın (1993), factors affecting the hereditary characteristics and learning experiences of the individual also affect their motivation. Because the motivation of the individual forms the basis of the learning process. In the learning process, the individual believes in success and the subject being learned is a curious and meaningful subject increases the level of motivation. According to Açikgöz (2003), highly motivated students are also students who facilitate the teacher's job in the learning environment. It is observed that discipline problems are minimized or even disappeared in groups with high motivation level students. In education environments where students with strong motivation also motivate their teachers, it is seen 
that the teacher starts to provide higher quality education by following the innovations.

Motivation is one of the most important psychological factors in the successful continuation of the education process (Yilmaz, 2007). One of the most important issues in the learning environment is that the teacher has information about the situation and motivation level of the classroom (Kara, 2008).

Kast and Rozenzweig (1985) defined motivation as supporting the movements of the individual in a certain direction and trying to gain certain behaviors to the individual. Motivation is the effort that constantly directs and mobilizes people to their goals (Ersen, 1997). At the same time, motivation is related to internal and external changes in the intensity, direction and quality of behavior (Palmer, 1993). In this context, the term motivation is the organized form of the factors that constitute motivational conditions and reactions and they are in a meaningful relationship with each other (Arık, 1996).

In Turkey, the motivation problem lies at the heart of the failure to achieve the desired goal in foreign language learning. Motivation, as a concept, is a vast topic and cannot be observed directly. The word 'motivation' is a derived term (Hubackova \& Semradova, 2014), and has mostly been defined as "processes that can energize and give direction to behavior, allow the behavior to continue and lead to a preference for a certain behavior" (Wlodkowski, 1991). It is commonly known that it is highly difficult for unmotivated students to succeed. Taşpınar (2004) proposed that sufficiently motivated learners are more likely to be successful in learning. Similarly, Dörnyei and Csizér (2005) noted that motivation plays a key role in academic education, particularly in foreign language learning. In a similar vein, McDonough (1981) advocated that motivation is a key factor affecting success in foreign language learning.

In Turkey, numerous problems exist with foreign language education (Suna \& Durmuscelebi, 2013). Of note, it is commonly noted that even students who have received English education for long years cannot use English effectively, although it has been shown that some private schools paying special attention to foreign language education have reached their target success. This phenomenon has given rise to the need for investigating the concept of motivation as a research problem with the aim of exploring the success levels of state and private school students in the English course.

In the light of these information, the present research was designed to compare motivational attitudes of elementary school students enrolled in state and private schools (grade 5-8) towards learning English. The research also aimed to examine students' motivational levels using the Academic Motivation Scale (AMS) developed by Vallerand, Blais, Brière and Pelletier (1989) and to investigate the reasons for students' low motivation (e.g., type of school enrolled, gender, type of primary school graduated, and educational level). In doing so, the study will help gain a deeper understanding of motivation and thereby will increase the integration of motivation in forthcoming educational processes. Foreign language education encompasses various techniques and strategies that are aimed to improve learners' motivational levels. However, these techniques and strategies may not provide the outcomes targeted by an individual in the absence of motivation. Therefore, the individual can only be successful by the aid of incentives along with the use of these techniques and strategies.

\section{Literature Review}

\subsection{Learning Motivation}

Learning motivation includes elements such as interest, attention, desire and curiosity directed to learning. Effective and lecturing of the learning teaching element is possible with the involvement of the individual. In order to learn effectively, the material learned must be meaningful and provide for the individual (Gagne \& Medsker, 1996). Jensen (1999) stated in research that the specific cycle of the brain goes back to the activities that the brain likes. Organizing the learning environment in a way that the learners will enjoy also increases the desire to learn and motivation (cited in Tok, 2008).

\subsection{The Importance of Motivation in Learning a Foreign Language}

The basis of the learning process is the individual's motivation (Acat \& Köşgeroğlu, 2006). Therefore, it is important for the individual to be involved and motivated. The relationship between motivation and academic success has been examined in various researches on motivation. According to the data obtained, motivation is the leading factor affecting the success in foreign language learning. According to Afzal, Ali, Khan and Hamid (2010), the most important factor governing behaviors in the learning process is motivation. Motivation factors are one of the prerequisites for success. The fulfillment of this prerequisite is possible with the participation of the students in the process and their positive attitude towards the course. When the students are not interested in the lesson, the lessons become boring and the subjects are not understood (Aydin, 2009). Student motivation is at the top of the list of necessary conditions for successful second language acquisition (Acat \& Demiral, 2002). 
It is seen that highly motivated students have long-term goals and learn the foreign language better when compared to other students. Strongly motivated students are students who are interested in the lesson, that is, well motivated (Spaulding, 1992). Highly motivated students are those who do not cause problems and even motivate their teachers in a positive way that all teachers want and appreciate (Çavuşoğlu, 2008).

According to Reece and Walker (1997), motivation is one of the key factors in the foreign language learning process (Cited in: Shirtless, 2001).

Different methods are used in foreign language learning to increase motivation and ensure permanence. Good and Brophy (1990) gather the elements required for the effective implementation of motivational methods and strategies and the success of the foreign language learning process under four main headings. These are:

- Creating a suitable classroom environment by educators

- Assigning homework suitable for the level of the student

- $\quad$ Processing subjects containing value and meaning

- Elements such as the use of motivational strategies (Good \& Brophy, 1990).

The strategies that should be done to ensure motivation in school are:

- Increasing students' self-confidence

- To determine the interests of the students

- To make learning valuable and meaningful

- $\quad$ Setting individual goals

- $\quad$ To make the learning environment interesting

- Identifying students' ideals

- Using reinforcements

- It can be listed as taking into account individual differences in the classroom setting (Good \& Brophy, 1990).

\subsection{Increasing Student Motivation in the Classroom}

In foreign language education, motivating the student to the lesson and maintaining this motivation is one of the main goals of educators. It was observed that students who were motivated positively in foreign language lessons also increased their success. According to Shinn (1994), it is important to motivate students by setting goals in foreign language teaching. These goals should be achievable and achievable. Students should be motivated according to the goals they set. Determining the strategy for the educators to motivate is similar to the architect's projecting a building. At the same time, some methods and strategies should be given to educators to increase student motivation and these strategies should be applied by the educators in accordance with the purpose of the course. Educators should ensure the participation of students in educational activities, take into account individual differences and have information about students' goals. In addition, students' awareness of foreign languages should be increased and an environment suitable for teaching should be prepared. In foreign language teaching, it is important to motivate students in line with their goals. In this context, to provide an effective learning environment:

- Students should have a say in determining classroom rules and determining the topics to be learned

- Lessons should be taught with elements that increase internal motivation, not with external motivation elements (such as punishment, threat and reward)

- Students should be provided with a suitable environment where they can both have fun and learn

- Students should be encouraged to learn

- An environment of respect should be created in the learning environment

- $\quad$ Student development should be controlled with midterm exams (Shinn, 1994).

Strategies that should be used to motivate students in the learning environment:

- Lessons should be made interesting

- The importance of the subjects to be covered should be stated

- Students should be motivated to learn 
- Students' self-efficacy level should be increased in subjects such as dance, music, drama, poetry

- The goal of the lesson should be announced at the beginning of the lesson

- The subject to be covered should be made meaningful

- Preliminary information should be given on the subject

- Expectation should be created against learning

- Reward, reinforcement and feedback should be used in the learning environment

- $\quad$ Students should be an example (role model).

2.4 Factors Affecting Student Motivation in Foreign Language Teaching

According to Eggen and Kauchak (1994), factors that negatively affect student motivation in foreign language learning:

- Traditional methods and techniques used in the educational environment

- $\quad$ Student group

- Attitude towards target language

- Tools and materials

- Number of students

- $\quad$ Equipment

- $\quad$ Factors such as the classroom environment.

Individual factors such as curiosity, awareness and anxiety also have an effect on increasing motivation in second language teaching. Raising awareness about foreign languages is an important factor in ensuring success. Especially arousing curiosity is one of the most effective ways to motivate students to the lesson (Eggen \& Kauchak, 1994).

To provide motivation in the learning environment:

- $\quad$ Selecting feasible projects

- Including creativity

- To give importance to elements that determine learning styles such as temperament, style, interest, ability, environment and time

- $\quad$ It is necessary to give feedback (Reid, 2007).

As a result, motivation phenomenon is valid for all lessons but it is indispensable for foreign language learning (Boynukara, 2009).

\subsection{Types of Motivation}

Gardner (1985) suggested that the type of motivation an individual has determines the answer to the question of why he/she learns a foreign language. The Self-Determination Theory is a theory of motivation that pays special attention to the internal resources of the individual. According to this theory, there are different types of motivation and some types provide better results compared to others (Deci \& Ryan, 2000; Lens, Vansteenkiste, \& Matos, 2000). As it is highly plausible that a single individual may have multiple different motivations, some recent researches focusing on the Self-Determination Theory have adopted an individual-centered approach, which posits that there are differences among individuals (Vansteenkiste, Sierens, Soenens, Luyckx, \& Lens, 2009). The fundamental motivational concept designated by the Self-Determination Theory divides motivation into two main types: intrinsic $v s$. extrinsic motivation. Intrinsic motivation refers to behavior that is driven by internal rewards while extrinsic motivation refers to the act of doing something for external rewards or avoiding the negative consequences of that act. As such, intrinsic motivation is considered a better form of motivation that arises from basic human needs (Deci \& Ryan, 1985).

\subsubsection{Extrinsic Motivation}

Extrinsic Motivation is the motivation that occurs outside of the individual, provided by external rewards. In Extrinsic Motivation, it is seen that activity depends on external rewards. It includes the researches done for the benefit to be obtained from outside (Burden, 1995).

Deci and Ryan (2000) suggests that social environments can facilitate or forestall intrinsic motivation by 
supporting versus thwarting people's innate psychological needs.

If there are expectations such as passing an exam and financial gains in return for an activity, we can say that this activity is external. At the same time, feedback, which has an important place in foreign language education, can be provided by extrinsic motivation sources (Williams \& Burden, 1997).

Extrinsic motivation is the external regulation of behaviors controlled by punishment and reward in social life. If a student is studying to meet the expectations of his/her family or teachers, this indicates that the student has an extrinsic motivation (Hidi, 2000).

According to research, most educators do not prefer activities that require long-term effort to be done with extrinsic motivation. According to Bruner (1962), after a while, students become dependent on reinforcers that are constantly given in the learning environment. Therefore, students should be motivated internally (Tok, 2008). In this context, when the reward is removed, the desire to learn and motivation may be lost.

Beneficial aspects of the reward in the learning environment are as follows:

- Making the student willing

- Motivating the student in achieving the goal

- It attracts attention to the learned subject

- Increasing student morale

- It can be considered to develop the feeling of "I" (Başaran, 1996).

The drawbacks of the award are:

- The award replaces the main purpose

- Resorting to undesirable means (cheating, etc.) to win an award

- The student provides unrequited benefits

- The suffering of the student when faced with failure.

Extrinsic motivation; It is divided into four main topics (Vallerand, Pelletier, Blais, Briére, Senécal, \& Valliéres, 1992).

- External regulation-Extrinsic motivation

- Intrinsic-Extrinsic motivation

- Determined-Extrinsic motivation

- Integrated-Extrinsic motivation

In External Regulation-Extrinsic Motivation, the motivated individual acts to get reward or to get rid of pressure. In Intrinsic-Extrinsic Motivation, the individual begins to internalize the reason for performing the behavior. But no matter how much they internalize, they are considered Extrinsically Motivated because they are motivated by past events. The student who is preparing for the exam thinks, "I have to start studying a few days before the exam, because this is a behavior expected from successful students", sets an example of Intrinsic External Motivation. In Determined-Extrinsic Motivation, behavior is perceived as the primary preference of the individual. Integrated-Extrinsic Motivation is the closest form of Extrinsic Motivation to Intrinsic Motivation. However, since the reason for performing the behavior depends on external factors, it is included under the title of Extrinsic Motivation (Vallerand et al., 1992).

\subsubsection{Intrinsic Motivation}

According to Köymen (2000), the motivation that ignites us, makes us lively and productive, and makes us enjoy working, is internal motivation. The best learning is seen in individuals who are intrinsically motivated. However, individuals with high motivation and a specific goal can be motivated to the lesson.

According to Raffini (1996); Behaviors without external coercion are the basis of internal motivation. For example, finding and exploring solutions to problems creates behaviors made with intrinsic motivation. Internal motivation; determines the control of the individual in decision making (Autonomy-Automony) and fires it; It mostly leads the individual to behaviors by making them feel successful (Competence-Competence); develops a sense of belonging to a group or community (Belonging/Relatedness); It creates self-esteem, the individual is happy with himself (Self-Esteem, Self-Esteem) and makes him enjoy what he does (Involvement).

According to Akbaba (2006), intrinsic motivation is the state of taking action voluntarily. The individual is 
focused on deep learning. An individual with high intrinsic motivation believes that his effort to work is worth it.

Although intrinsic motivation is clearly an important type of motivation, most of the activities people do are not intrinsically motivated (Deci \& Ryan, 2000). Indeed, many activities in work organizations are not intrinsically interesting and the use of strategies such as participation to enhance intrinsic motivation is not always feasible (Gagne \& Deci, 2005).

The main factor that drives the individual to success is the intrinsic motivation he has. If the task undertaken by the individual reveals his abilities, then it is interesting to him. Taking part in an educational environment positively affects the intrinsic motivation level of the individual. Finding the opportunity to improve the knowledge and skills of the individual creates the desire for self-cultivation, which increases the internal motivation (Başaran, 2000).

People who are intrinsically motivated feel that they are doing an activity because they have chosen to do so voluntarily and because the activity represents a challenge to their existing competencies and require them to use their creative capabilities. This kind of motivation is considered to be highly self-determined in the sense that the reason for doing the activity is linked solely to the individual's positive feelings while performing the task (Noels et al., 1999).

The view that external audit, which was accepted in the past, will be replaced by internal audit has started to lose its validity today. According to many researches, it is stated that external control prevents the development process of internal motivation (Deci \& Ryan, 1985).

Intrinsic motivation is that the individual values the work even when not facing any external pressure. However; he defends the view that there are many methods that increase internal motivation and that these methods can bring many benefits. Autonomy thought arises from the need to make one's own decisions, and the sense of responsibility develops only if the behaviors that the individual should do are not imposed (Stipek, 1988).

Lier (1996) compares motivation to an example of money. Whether money is considered good or bad depends on what is done with it. If intrinsic motivation is our own extrinsic motivation, it's like money borrowed from another person. Motivation can be wasted like money, or it can be spent sparingly. We borrow some genetically and the other part through our friends and external stimuli. Being highly motivated is like having a lot of money. Motivation can be spent sparingly or wasted. Motivation is a valuable capital that should be spent carefully and smartly in the learning market (Ünal \& Bursal, 2013). At the same time, it is possible to perform education and training without difficulty in learning environments where internal motivation is high (Özbay, 2006).

Students with strong intrinsic motivation are people who have developed independent decision-making abilities who choose difficult goals. These are individuals who can work independently and have intrinsic criteria (such as curiosity, interest, desire and attention) as success criteria. In addition, students with strong extrinsic motivation; They prefer easy goals, they aim to please the teacher by acting dependent on the teacher, grade as a success criterion, etc. they act on external criteria (Williams \& Burden, 1999).

The knowledge and skills to be learned should be compatible with the child's age, interest and psychology. One of the most important sources of internal motivation, drive, interest and curiosity can be examined under subheadings (Ünal \& Bursal1, 2013). In environments where internal motivation is provided, it is possible to conduct education without any problems (Özbay, 2006).

Intrinsic motivation:

- Intrinsic motivation for experience

- Intrinsic motivation to know

- It has been examined under three subtitles as motivation to succeed (Vallerand et al., 1992).

Motivation for Experience is about attachment to behavior with internal arousal, Intrinsic Motivation for Knowing is about making an effort to learn new things, and Intrinsic Motivation for Success is about the effort of the individual (Vallerand \& Ratella, 2004). Intrinsic Motivation for Knowing; It is the urge to continue the behavior as the individual enjoys and is satisfied with learning and discovering something new. Internal factors govern the behavior. For example, reading a book shows that the student has a strong "Intrinsic Motivation to Know" level because he enjoys learning and exploring. "Intrinsic Motivation to Achieve" is the individual's taking action because he enjoys introducing new things and accomplishing something. For example, studying indicates that a student has a high motivation to succeed because he enjoys being successful and feels happy.

The general purpose of this research is to examine the motivational attitudes of state and private elementary school students in English course. In the research, answers to the following questions were sought on the basis of 
this general purpose:

1) Do students' motivational attitudes towards the English course vary between the two school types?

2) Do students' motivational attitudes towards the English course vary according to the type of primary school they graduated from?

3) Do students' motivational attitudes towards the English course vary according to gender?

4) Is there a relationship between the motivational attitudes of the students researching in both state and private elementary schools according to their grade levels?

5) Is there a relationship between the motivational attitudes of the students researching in state schools according to their grade levels?

6) Is there a relationship between the motivational attitudes of the students researching in private schools according to their grade levels?

\section{Method}

\subsection{Research Design}

The research was designed as a descriptive survey model. In this model, data are collected to test hypotheses regarding the research problem or to find answers to predefined questions (Karasar, 2006).

\subsection{Universe and Sample}

The universe of the research encompassed all the elementary school students (grade 5-8) enrolled in the state and private schools in Adana province. Within this universe, a total of 747 students enrolled in a Private Elementary School and a State Elementary School during the academic year 2018-2019 were randomly sampled. In the education programs of both school types, the weekly number of English lessons is 4 hours, and the number of students in the classes is approximately 30 people and they are equal to each other.

\subsection{Data Collection Tools}

Only quantitative data were collected in the research, using the Academic Motivation Scale (AMS) which was developed by Vallerand et al. (1989) and revised by Vallerand et al. (1992) based on the Autonomy Theory and was adapted to Turkish by Karagüven (2012). The internal consistency and reliability of AMS was calculated using the Cronbach Alpha coefficient, which yielded a value of .88, thus indicating that the scale was a reliable and acceptably compatible scale. AMS consists of 28 items divided among 7 subscales:

1) Intrinsic motivation to know

2) Intrinsic motivation towards accomplishment

3) Intrinsic motivation to experience stimulation

4) Interjected regulation

5) External regulation

6) Identified regulation

7) Amotivation

\subsection{Data Analysis}

The scale was administered to all the 747 students and then the responses were transferred to the computer environment and were analyzed using statistical software. Motivational attitudes of students in both schools were analyzed using the Pearson product-moment correlation coefficient and Independent samples $t$-test. Statistical results were categorized by the researchers in terms of school type, type of primary school graduated, gender, and educational level.

\section{Results}

4.1 Motivational Attitudes According to School Type

Students' motivational attitudes according to their school type (i.e., state $v s$. private) were analyzed using $t$-test and the results were presented in Table 1. 
Table 1. Students' motivational attitudes according to school type

\begin{tabular}{llllllll}
\hline Subscales & School type & $\mathbf{N}$ & $\mathbf{\mathbf { x }}$ & $\mathbf{S d}$ & $\mathbf{d f}$ & $\mathbf{t}$ & $\mathbf{p}$ \\
\hline Intrinsic motivation to know & Private & 356 & 22.21 & 5.35 & 745 & -.411 & .681 \\
& State & 391 & 22.37 & 5.33 & & & \\
Intrinsic motivation towards & Private & 356 & 20.51 & 5.77 & 745 & -2.319 & $.021^{*}$ \\
accomplishment & State & 391 & 21.46 & 5.38 & & & \\
Intrinsic motivation to experience & Private & 356 & 16.08 & 5.94 & 745 & -4.328 & $.000^{*}$ \\
stimulation & State & 391 & 17.95 & 5.87 & & & .249 \\
Identified regulation & Private & 356 & 24.33 & 4.77 & 745 & 1.154 & .249 \\
& State & 391 & 23.92 & 4.99 & & & $.005^{*}$ \\
Introjected regulation & Private & 356 & 18.21 & 7.01 & 745 & -2.830 & \\
& State & 391 & 19.61 & 6.52 & & & .327 \\
External regulation & Private & 356 & 20.85 & 5.37 & 745 & -.980 & .057 \\
Amotivation & State & 391 & 21.23 & 5.20 & & & \\
& Private & 356 & 8.04 & 5.71 & 745 & -1.905 & \\
\hline
\end{tabular}

Note. $* p<.05$.

As seen in Table 1, private school students obtained significantly higher scores in the subscales including "Intrinsic motivation towards accomplishment" [t(745), $-2.319, p=.021]$, "Intrinsic motivation to experience stimulation" [ $\mathrm{t}(745),-4.328, p=.000]$, and "Introjected regulation" [ $\mathrm{t}(745),-2.830, p=.005]$ compared to state school students. However, no significant difference was found between the two school types with regard to "Intrinsic motivation to know" [t(745), -.411, $p=.681]$, "Identified regulation" [t(745), 1.154, $p=.249]$, "External regulation" [t(745), -.980, $p=.327]$, and "Amotivation" [t(745), -1.905, $p=.057](p>.05)$.

\subsection{Motivational Attitudes According to the Type of Primary School Graduated}

Students' motivational attitudes according to the type of primary school the students graduated from (i.e., private vs. state) were analyzed using t-test and the results were presented in Table 2.

Table 2. Students' motivational attitudes according to the type of primary school graduated

\begin{tabular}{llllllll}
\hline Subscales & PSG & $\mathbf{N}$ & $\overline{\mathbf{x}}$ & $\mathbf{S d}$ & $\mathbf{d f}$ & $\mathbf{t}$ & $\mathbf{p}$ \\
\hline Intrinsic motivation to know & Private & 37 & 23.08 & 5.04 & 745 & .926 & .355 \\
& State & 710 & 22.25 & 5.35 & & & \\
Intrinsic motivation towards & Private & 37 & 22.19 & 5.62 & 745 & 1.318 & .188 \\
accomplishment & State & 710 & 20.95 & 5.58 & & & \\
Intrinsic motivation to experience & Private & 37 & 18.54 & 6.54 & 745 & 1.552 & .121 \\
stimulation & State & 710 & 16.98 & 5.93 & & & \\
Identified regulation & Private & 37 & 24.24 & 5.22 & 745 & .167 & .868 \\
& State & 710 & 24.11 & 4.87 & & & \\
Introjected regulation & Private & 37 & 21.00 & 6.35 & 745 & 1.895 & .058 \\
& State & 710 & 18.83 & 6.80 & & & \\
External regulation & Private & 37 & 21.59 & 4.80 & 745 & .647 & .518 \\
Amotivation & State & 710 & 21.02 & 5.31 & & & \\
& Private & 37 & 11.40 & 7.70 & 745 & 3.013 & $.003 *$ \\
\hline
\end{tabular}

Note. ${ }^{*} p<.05$.

\section{PSG: Primary School Graduated}

As revealed in Table 2, the students graduated from a state primary school had significantly higher scores than the students graduated from a private school with regard to "Amotivation" [t(745), 3.013, $p=.003]$. Nevertheless, no significant difference was observed between the two types of primary schools with regard to "Intrinsic motivation to know" [t(745), .926, $p=.355]$, "Intrinsic motivation towards accomplishment" [t(745), $1,138, p=.188]$, "Intrinsic motivation to experience stimulation" [ $\mathrm{t}(745), 1.552, p=.121]$, "Identified regulation" $[\mathrm{t}(745), .167, p=.868]$, “Introjected regulation" [t(745), 1.895, $p=.058]$, and "External regulation" [t(745), .647, $p=.518](p>.05)$. 


\subsection{Motivational Attitudes According to Gender}

Students' motivational attitudes according to gender were analyzed using $t$-test and the results were presented in Table 3.

Table 3. Students' motivational attitudes according to gender

\begin{tabular}{|c|c|c|c|c|c|c|c|}
\hline Subscales & Gender & $\mathbf{N}$ & $\overline{\mathbf{x}}$ & SD & df & $\mathbf{t}$ & $\mathbf{p}$ \\
\hline \multirow[t]{2}{*}{ Intrinsic motivation to know } & Female & 342 & 22.59 & 5.16 & 745 & 1.434 & .152 \\
\hline & Male & 405 & 22.03 & 5.48 & & & \\
\hline \multirow{2}{*}{$\begin{array}{l}\text { Intrinsic motivation towards } \\
\text { accomplishment }\end{array}$} & Female & 342 & 21.26 & 5.57 & 745 & 1.128 & .260 \\
\hline & Male & 405 & 20.80 & 5.60 & & & \\
\hline \multirow{2}{*}{$\begin{array}{l}\text { Intrinsic motivation to experience } \\
\text { stimulation }\end{array}$} & Female & 342 & 17.34 & 5.92 & 745 & 1.198 & .231 \\
\hline & Male & 405 & 16.82 & 6.01 & & & \\
\hline \multirow[t]{2}{*}{ Identified regulation } & Female & 342 & 24.39 & 4.72 & 745 & 1.422 & .156 \\
\hline & Male & 405 & 23.88 & 5.02 & & & \\
\hline \multirow[t]{2}{*}{ Introjected regulation } & Female & 342 & 18.62 & 6.86 & 745 & -1.189 & .235 \\
\hline & Male & 405 & 19.21 & 6.73 & & & \\
\hline \multirow[t]{2}{*}{ External regulation } & Female & 342 & 20.54 & 5.27 & 745 & -2.428 & $.015^{*}$ \\
\hline & Male & 405 & 21.48 & 5.26 & & & \\
\hline \multirow[t]{2}{*}{ Amotivation } & Female & 342 & 7.21 & 5.11 & 745 & -5.321 & $.000^{*}$ \\
\hline & Male & 405 & 9.55 & 6.63 & & & \\
\hline
\end{tabular}

Note. ${ }^{*} p<.05$

As shown in Table 3, male students obtained significantly higher scores in "External regulation" [t(745), -2.428, $p=.015]$ and "Amotivation" [t(745), -5.321, $p=.000]$, whereas no significant difference was found between male and female students with regard to "Intrinsic motivation to know" [t(745), 1.434, $p=.152]$, "Intrinsic motivation towards accomplishment" [t(745), 1.128, $p=.260]$, "Intrinsic motivation to experience stimulation" $[\mathrm{t}(745), 1.198, p=.231]$, "Identified regulation" [ $\mathrm{t}(745), 1.422, p=.156]$, and "Introjected regulation" [t(745), $-1.189, p=.235](p>.05)$.

\subsection{Motivational Attitudes of Students According to the Educational Level}

The motivational attitudes of state and private elementary school students according to their educational level were analyzed using the Pearson product-moment correlation coefficient and the results were presented in Table 4.

Table 4. Correlations between students' motivational attitudes and their educational level

Note. $* p<.05$

\begin{tabular}{llll}
\hline Subscales & $\mathbf{N}$ & $\mathbf{r}$ & $\mathbf{p}$ \\
\hline Intrinsic motivation to know & 747 & -.050 & .175 \\
Intrinsic motivation towards accomplishment & 747 & -.051 & .165 \\
Intrinsic motivation to experience stimulation & 747 & .018 & .616 \\
Identified regulation & 747 & .070 & .056 \\
Introjected regulation & 747 & -.015 & .678 \\
External regulation & 747 & -.007 & .856 \\
Amotivation & 747 & -.053 & .150 \\
\hline
\end{tabular}

As can be seen in Table 4, no significant correlation was found between students' educational level and "Intrinsic motivation to know" [r(747), - $0.5, p=.175]$, "Intrinsic motivation towards accomplishment" $[\mathrm{r}(747)$, $-0.51, p=.165]$, "Intrinsic motivation to experience stimulation" $[\mathrm{r}(747), .18, p=.616]$, "Identified regulation" [r(747), .070, $p=.056]$, "Introjected regulation" $[\mathrm{r}(747),-015, p=.678]$, "External regulation" $[\mathrm{r}(747),-.007, p$ $=.856]$, and "Amotivation" [r(747), -.053, $p=.150](p>0.5)$.

\subsection{Motivational Attitudes of State School Students According to the Educational Level}

The motivational attitudes of state elementary school students according to their educational level were analyzed using the Pearson product-moment correlation coefficient and the results were presented in Table 5. 
Table 5. Correlations between state school students' motivational attitudes and their educational level

\begin{tabular}{llll}
\hline Subscales & $\mathbf{N}$ & $\mathbf{r}$ & $\mathbf{p}$ \\
\hline Intrinsic motivation to know & 391 & .024 & .632 \\
Intrinsic motivation towards accomplishment & 391 & .027 & .601 \\
Intrinsic motivation to experience stimulation & 391 & .089 & .080 \\
Identified regulation & 391 & $.105^{*}$ & $.038^{*}$ \\
Introjected regulation & 391 & .075 & .139 \\
External regulation & 391 & .029 & .564 \\
Amotivation & 391 & -.037 & .468 \\
\hline
\end{tabular}

Note. ${ }^{*} p<.05$

As shown in Table 5, a significant correlation was found between state school students' educational level and "Identified regulation" $[\mathrm{r}(391), 105, p=.038]$, whereas no significant correlation was found between their educational level and "Intrinsic motivation to know" [r(391), - $0.24, p=.632]$, "Intrinsic motivation towards accomplishment" [r(391), -.027, $p=.601]$, "Intrinsic motivation to experience stimulation" [r(391), 089, $p ., 080]$, "Introjected regulation" $[\mathrm{r}(391), 075, p=.139]$, "External regulation" $[\mathrm{r}(391)-.029, p=.564]$, and "Amotivation" $[\mathrm{r}(391)-.037, p=.468](\mathrm{p}>.05)$.

\subsection{Motivational Attitudes of Private School Students According to the Educational Level}

The motivational attitudes of private elementary school students according to their educational level were analyzed using the Pearson product-moment correlation coefficient and the results were presented in Table 6.

Table 6. Correlations between private school students' motivational attitudes and their educational level

\begin{tabular}{llll}
\hline Subscales & $\mathbf{N}$ & $\mathbf{r}$ & $\mathbf{p}$ \\
\hline Intrinsic motivation to know & 356 & $-.137^{* *}$ & $.010^{* *}$ \\
Intrinsic motivation towards accomplishment & 356 & $-.146^{* *}$ & $.006^{* *}$ \\
Intrinsic motivation to experience stimulation & 356 & -.083 & .119 \\
Identified regulation & 356 & .034 & .518 \\
Introjected regulation & 356 & $-.126^{*}$ & $.018^{*}$ \\
External regulation & 356 & -.051 & .333 \\
Amotivation & 356 & -.084 & .113 \\
\hline
\end{tabular}

Note. $* p<.05, * * p<.01$.

As shown in Table 6, a significant negative correlation was detected between private school students' educational level and "Intrinsic motivation to know" [r(356), -.137, $p=.010]$, "Intrinsic motivation towards accomplishment" [r(356), -1.46, $p=.006]$, and "Introjected regulation" $[\mathrm{r}(356),-1.26, p=.018]$. However, no significant correlation was found between private school students' educational level and "Intrinsic motivation to experience stimulation" $[\mathrm{r}(356),-.083, p=.119]$, "Identified regulation" $[\mathrm{r}(356), .034, p=.518]$, "External regulation" [r(356), -.051, $p=.333]$, and "Amotivation" [r(356), -.084, .113] $(p>0.5)$.

\section{Conclusion, Discussion, and Recommendations}

The results indicated that, students graduated from a private primary school were found to have significantly higher "Amotivation" scores compared to students graduated from a state primary school, whereas no significant difference was found between graduated from a state or primary school with regard to "Intrinsic motivation to know", "Intrinsic motivation towards accomplishment", "Intrinsic motivation to experience stimulation", "Identified regulation", "Introjected regulation", and "External regulation". In a similar fashion, previous researches found no significant difference between English-language teachers working at state and private schools with regard to their emphasis on the use of motivation strategies (Dörnyei, 1994). Accordingly, the results obtained in our research are consistent with those reported.

On the other hand, In terms of gender, it was revealed in both schools, male students had significantly higher scores than female students with regard to "Introjected regulation" and "External regulation", In the literature, however, contradictory findings have been reported; while some researches reported higher scores for female students in terms of "Introjected regulation", some others reported higher scores for male students in terms of "External regulation", "Amotivation", and "Identified regulation" (Vallerand et al., 1992; Spittle, Jackson, \& Casey, 2009; Hegarty, 2010; Aluçdibi \& Ekici, 2012). 
In addition, the Pearson Correlation Coefficient indicated a significant negative correlation between private school students' educational level and "Intrinsic motivation to know", "Intrinsic motivation towards accomplishment", and "Introjected regulation. In a similar vein, previous researches indicated that students' intrinsic and extrinsic motivations decrease as their educational level increases (particularly when moving from grade 7 to grade 8) (Brouse, Basch, LeBlanc, McKnight, \& Lei, 2010). Meaningfully, the higher motivational levels among first-grade students as compared to final-grade students could be associated with their being at the very beginning of their education.

Based on the results of the present research, following recommendations can be made, particularly for future researches investigating educational sciences:

Students should be made well aware of the fact that learning English is a prerequisite for getting a good job. They should also be explained about the educational goals of the course as well as the reason as to why they should research each topic. Moreover, students should be allowed to perceive the English course not as an obstacle but as a step improving their quality of life. In this regard, they could be regularly reminded of the fact that English is the common language of science and communication in the whole world. On the other hand, using written and online materials to inform students about the fact that having English competence could allow them to access more information could be useful for increasing their motivation. In a learning environment, the teacher has the greatest responsibility in ensuring students' motivation, and students' motivation is largely dependent on the teacher's motivation. Accordingly, teachers should continuously keep up-to-date with current developments and should choose appropriate motivation strategies and activities based on students' personal characteristics and abilities to improve their intrinsic motivation and active participation in class.

In addition, with this study, it has been aimed that teachers recognize the factors that affect their students 'motivation in English lessons and raise awareness about how to increase their students' motivation. On the other hand, besides this descriptive research, a mixed method should be preferred to do new research on similar subjects both quantitatively and qualitatively.

\section{Acknowledgements}

This research was adapted from a Master's Thesis titled "Comparison of Attitudes of State and Private Elementary School Students' About Their Motivation in the English Course: Adana Province Example" and was presented as a verbal presentation at the "4th International Cukurova Scientific Research Congress" held in Adana on 21-23 February 2020.

\section{References}

Acat, B., \& Demiral, S. (2002). Sources of motivation in learning foreign language in Turkey. Educational Administration in Theory \& Practice, 31, 312-329. https://doi.org/10.14527/9786053644309.01

Acat, B. M., \& Köşgeroğlu, N. (2006). Motivation's resources and problems scale. Anatolian Journal of Psychiatry, 7(4), 204-210.

Açıkgöz, K. Ü. (2003). Effective learning and teaching. Education World Publications.

Afzal, H., Ali, I., Khan, M. A., \& Hamid, K. (2010). A study of university students' motivation and its relationship with their academic performance. International Journal of Business and Management, 5(4). https://doi.org/10.5539/ijbm.v5n4p80

Akbaba, S. (2006). Motivation in education. Kazım Karabekir Journal of Education Faculty, 13, 343-361.

Aktaş, İ. (2011). The effect of teaching based on the 4 MAT teaching method on the achievement, motivation and learning styles of seventh grade students in the unit of structure and properties of matter. Unpublished master thesis. Mustafa Kemal University. https://doi.org/10.34137/jilses.431971

Aluçdibi, F., \& Ekici, G. (2012). The analysis of biology course motivation levels of elementary education students in terms of different variables. Abant Izzet Baysal University Journal of Education Faculty, 12(1), $197-227$.

Arı, İ. A. (1996). Introduction to motivation and excitement. Çantay Publishing House.

Atkinson, R. L., Atkinson, R. C., \& Hilgard, E. R. (1995). Introduction to Psychology I-II. Social Publications.

Aydin, F. (2009). The effects of cooperative learning method on success, attitude and motivation in tenth grade geography lesson. Unpublished doctora thesis. Gazi University.

Aydın, M. (1993). Contemporary education control. Pegem A Publications. 
Başaran, E. İ. (1996). Education Management. Change Publications.

Başaran, E. İ. (2000). Organizational behavior. Umut Publication Distribution.

Boynukara, H. (2009). The necessary conditions for foreign language teaching must be provided. Education Overview, 14, 12-14.

Brouse, C. H., Basch, C. E., LeBlanc, M., McKnight, K. R., \& Lei, T. (2010). College students' academic motivation: differences by gender, class, and source of payment. College Quarterly, 13, 1-10.

Bruner, J. (1962). On knowing: Essays for the left hand. Harward University Press. https://doi.org/10.1097/00005053-196210000-00014

Burden, R. P. (1995). Classroom management and discipline methods to facilitate cooperation and instruction. Longman Publishers.

Çavuşoğlu, D. (2008). The effects of Turkish language and literature teachers' motivational competencies on student achievement. Unpublished master thesis. Yeditepe University.

Deci, E. L., \& Ryan, R. M. (1985). Intrinsic motivation and self-determination in human behavior. Plenum. https://doi.org/10.1007/978-1-4899-2271-7

Deci, E. L., \& Ryan, R. M. (2000). Intrinsic and extrinsic motivations: classic definitions and new directions. Contemporary Educational Psychology, 25, 54-67. https://doi.org/10.1006/ceps.1999.1020

Dörnyei, Z. (1994). Motivation and motivating in the foreign language classroom. The Modern Language Journal, 78, 273-284. https://doi.org/10.1111/j.1540-4781.1994.tb02042.x

Dörnyei, Z., \& Csizér, K. (2005). Language learners' motivational profiles and their motivated learning behavior. Language Learning Research Club Journal, 55(4), 613-659. https://doi.org/10.1111/j.0023-8333.2005.00319.x

Eggen, P., \& Kauchak, D. (1994). Educational psychology classroom connections. Macmillan Publishing Company.

Ersen, H. (1997). Total quality and human resources relationship, efficiency and, way to be effectiveness. Alfa.

Gagne, M., \& Deci, E. L. (2005). Serf Determination theory and work motivation. Journal of Organizational Behavior, 26(4), 331-362. https://doi.org/10.1002/job.322

Gardner, R. C. (1985). Social psychology and second language learning: The role of attitudes and motivation. Edward Arnold.

Gömleksiz, M. N. (2003). Validity and reliability of an attitude scale on affective domain in English course. Firat University Journal of Social Science, 13(1), 215-226.

Good, T., \& Brophy, J. (1990). Looking in classrooms. Harper Collins Publishers.

Hegarty, J. (2010). Application of the academic motivation scale to graduate school student. The Journal of Human Resource and Adult Learning, 6(2), 48-55.

Hidi, S. (2000). An interest researcher's perspective: The effects of extrinsic and intrinsic factors on motivation. In C. Sansone \& J. M. Harackiewicz (Eds.), Intrinsic and extrinsic motivation: The search for optimal motivation and performance. Academic Press. https://doi.org/10.1016/b978-012619070-0/50033-7

Hubackova, S., \& Semradova, I. (2014). Research research on motivation in adult education. Procedia-Social and Behavioral Sciences, 159, 396-400. https://doi.org/10.1016/j.sbspro.2014.12.395

Jensen, C. R. (1995). Outdoor recreation in America. Human Kinetics.

Kara, A. (2008). Adaptation of the "echelle de motivation en education" scale to Turkish. Ege Journal of Education, 9(2), 59-78.

Karagüven, M. H. (2012). Adaptation of the academic motivation scale to Turkish. Educational Sciences: Theory and Practice, 12(4), 2599-2620. https://doi.org/10.1037/t71717-000

Karasar, N. (2006). Scientific research method. Nobel Publishing Distribution.

Kast, F. E., \& Rosenzweig, J. E. (1985). Organisation and management. Mc Graw Hill.

Koçel, T. (1995). Business management. Beta Publishing Distribution.

Köymen, Ü. (2000). Motivational learning. Eğitim-Sen Publications. 
Lens, W., Vansteenkiste, M., \& Matos, L. (2009). Motivation: quantity and quality matter. Wydawnictwo KUL.

Lier, L. V. (1996). Interaction in the language curriculum, awareness, autonomy \& authenticity. Longman.

McDonough, S. H. (1981). Psychology in foreign language teaching. George Allen \& Unwin.

Noels, K. A., Clement, R., \& Pellettier, L. G. (1999). Perceptions of teachers' communitative style and students' intrinsic and extrinsic motivation. The Modern Language Journal, 88, 23-34. https://doi.org/10.1111/0026-7902.00003

Özbay, Y. (2006). Developmental and learning psychology. Academy Bookstore.

Palmer, J. M. (1993). Performance reviews, personal development, and management sequence. Rota Publications.

Reece, I., \& Walker, S. (1997). Teaching, training, and learning. a practical guide (3rd ed.). Business Education Publishers Limited.

Reid, G. (2007). Motivating learners in the classroom: Ideas and strategies. Paul Chapman Publishing.

Shinn, G. (1994). The miracle of motivation. Tyndale House Publishers.

Spaulding, C. L. (1992). Motivation in the classroom. McGraw-Hill.

Spittle, M., Jackson, K., \& Casey, M. (2009). Applying self-determination theory to understand the motivation for becoming a physical education teacher. Teaching and Teacher Education, 2(1), 190-197. https://doi.org/10.1016/j.tate.2008.07.005

Stipek, D. J. (1988). Motivation to learn. Prentice Hall.

Suna, Y., \& Durmuş̧lebi, M. (2013). A Compilation Work About Why Turkey Suffers from Learning and Teaching English. OPUS International Society Research Journal, 3(5).

Taşpınar, H. (2004). Teachers' and students' perceptions of teachers' task-related motivational strategy use and students' motivation levels. Unpublished doctora thesis. Bilkent University.

Tok, T. N. (2008). Motivate the student in the classroom. Kriter Publishing House.

Ünal, F., \& Bursalı, H. (2013). Turkish teachers' views on motivation factors. Middle Eastern \& African Journal of Educational Research, 5, 7-16.

Vallerand, R. J. (2004). Intrinsic and extrinsic motivation in sport. Encyclopedia of Applied Psychology, 2, 427-435. https://doi.org/10.1016/b0-12-657410-3/00835-7

Vallerand, R. J., Blais, M. R., Brière, N. M., \& Pelletier, L. G. (1989). Construction and validation of the motivation scale in education. Canadian Journal of Behavioral Sciences, 21, 323-349. https://doi.org/10.1037/h0079855

Vallerand, R. J., Pelletier, L. G., Blais, M. R., Briére, N. M., Senécal, C., \& Valliéres, E. F. (1992). The academic motivation scale: A measure of intrinsic, extrinsic, and amotivation in education. Educational and Psychological Measurement, 52, 1003-1017. https://doi.org/10.1177/0013164492052004025

Vansteenkiste, M., Sierens, E., Soenens, B., Luyckx, K., \& Lens, W. (2009). Motivational profiles from a self-determination perspective: the quality of motivation matters. Journal of Educational Psychology, 101, 671-688. https://doi.org/10.1037/a0015083

Williams, M., \& Burden, R. L. (1999). Psychology for language teachers. Cambridge University Press.

Wlodkowski, R. J. (1991). Motivation and teaching. National Education Association.

Y1lmaz, E. (2007). The role of motivation in student achievement in secondary education English lessons: Bartın province example. Unpublished master thesis. Karaelmas University.

\section{Copyrights}

Copyright for this article is retained by the author, with first publication rights granted to the journal.

This is an open-access article distributed under the terms and conditions of the Creative Commons Attribution license (http://creativecommons.org/licenses/by/4.0/). 